\title{
Erratum to: Planning for implementation
}

\author{
George V. Wickstrom ${ }^{1} \cdot$ Albert A. Grant $^{1}$
}

\section{Erratum to: Transportation DOI 10.1007/BF00172390}

In the original publication of this article, the second author name had been incorrectly published. The correct name of second author is given below:

Albert A. Grant

The online version of the original article can be found under doi:10.1007/BF00172390.

\section{George V. Wickstrom}

1 National Capital Region Transportation Planning Board, Metropolitan Washington Council of Governments, Washington, DC, USA 